\title{
Malignant Lymphomas in Patients with Autoimmune Diseases: A Report of 6 Cases and a Review of the Japanese Literature
}

\author{
Susumu Sugai, Junko Tachibana, Makoto Sawada, Shiro Shimizu, \\ Yuko Hirose, Tomoo Thkiguchi and Susumu Kondi
}

\begin{abstract}
Six patients with malignant lymphomas in autoimmune diseases are described. Four patients who had Sjögren's syndrome (SS) alone or with progressive systemic sclerosis (PSS) or rheumatoid arthritis (RA) developed non-Hodgkin's lymphomas of the B cell type. One patient who had systemic lupus erythematosus (SLE) developed a B cell lymphoma. Another patient with chronic thyroiditis (ChTD) and idiopathic thrombocytopenic purpura (ITP) had a T cell (OKT3/T4) lymphoma. In 5 patients, the autoimmune diseases (2SS, SS/PSS, SS/RA and SLE) preceded B cell lymphomas by one to 11 years. In the patient with ChTD/ITP, ChTD and a malignant lymphoma were found simultaneously. A review of Japanese reports on lymphoproliferative disorders associated with these autoimmune diseases is given. This report offers the suggestion that disorders in the immunoregulatory system caused by autoimmune diseases may predispose lymphoproliferative disorders.
\end{abstract}

Key Words: Lymphoproliferative disorders, Sjögren's syndrome, Rheumatoid arthritis, Sytemic lupus ery thematosus, Chronic thyroiditis and Idiopathic thrombocytopenic purpura

A high incidence of lymphoproliferative disorders has been suggested to occur in various autoimmune diseases such as Sjögren's syndrome $(\mathrm{SS})^{1,2)}$, rheumatoid arthritis $(\mathrm{RA})^{3,4)}$, systemic lupus erythematosus (SLE) ${ }^{5,6)}$, chronic thyroiditis $(\mathrm{ChTD})^{7,8)}$, and idiopathic thrombocytopenic purpura (ITP $)^{9,10)}$. The association of malignant lymphomas in SS is well known and interesting because SS is characterized by a dynamic spectrum of lymphoproliferative disorders ranging from benign polyclonal lymphoid hyperplasia to malignant lymphomas with monoclonal B cell characteristics $^{11,12)}$. The association of lymphoid malignancy with other autoimmune diseases such as RA, SLE, ChTD and ITP is also considered to be significant $^{4,6,8,10)}$.

In this report we present 6 malignant lymphomas (5 B cell and one $\mathrm{T}$ cell lymphomas) in patients with autoimmune diseases (2SS, SS/progressive systemic sclerosis (PSS), SS/RA, SLE and ChTD/ITP) and also a review of lymphoproliferative disorders in Japanese patients with these autoimmune diseases.

\section{METHODS}

The blastogenic responses of peripheral blood lymphocytes (PBL) to phytohemagglutinin-P (PHA-P), concanavalin A (Con A) and pokeweed mitogen (PWM) were examined ${ }^{13)}$. Spontaneous rosette-forming cells (E-RFC) and complement rosette-forming cells (EAC-RFC) were determined by the method of Jondal et $\mathrm{al}^{14)}$. Reactions to common recall antigens (DTH) such as tuberculin purified protein derivative (PPD), streptokinase/ sterptodornase (SK/SD), candida albicans and mumps antigen were assessed ${ }^{15)}$.

Immunofluorescence method: Direct and indirect immunofluorescence methods were used. The cell populations were examined for surface membrane immunoglobulin (SmIg) and cytoplasmic Ig (CIg) by the direct staining method ${ }^{15)}$. FITC-labeled monospecific anti-human Ig and antirabbit IgG antisera were purchased from Hoechst Behring Institute (Frankfurt, West Germany) and used at a concentration of $1 \mathrm{mg} / \mathrm{ml}$.

Immunoperoxidase staining ${ }^{16)}$ : Paraffin em-

From the Section of Hematology and Immunology, Department of Internal Medicine,

Kanazawa Medical University, Ishikawa Pref.

Received for publication April 22, 1987.

Reprint request to: Susumu Sugai, MD, Section of Hematology and Immunology, Department of Internal Medicine, Kanazawa Medical University, 1-1, Uchinada-machi, Kahoku-gun, Ishikawa 920-02, Japan. 
bedded tissues were examined using the Dako PAP kit (Dako Corp. Santa Barbara, CA., USA). The tissues were incubated in $0.1 \%$ trypsin at $37^{\circ} \mathrm{C}$ for $15 \mathrm{~min}$ prior to application of the primary antisera.

\section{CASE REPORTS}

Case 1. The patient was a 67-year-old woman with B cell malignant lymphoma and SS with PSS. The onset of Raynaud's phenomenon occurred in 1971. In 1976 she was examined in our hospital for dry mouth and polyarthralgia which had persisted for 5 years. Physical examination revealed sclerosis of the fingers, face and chest, and angular cheilitis. Pulmonary fibrosis and hypomotility of the esophagus were disclosed. Abnormal Schirmer's test results and keratoconjunctivitis sicca (KCS) were present. The salivary flow rate had decreased and sequential salivary scintigraphy was abnormal. The erythrocyte sedimentation rate (ESR) was 32 $\mathrm{mm} / \mathrm{hr}$, gammaglobulin was $2.0 \mathrm{~g} / \mathrm{dl}$ with $\mathrm{IgG}$ 2,488, IgA 390 and IgM $162 \mathrm{mg} / \mathrm{dl}$ and rheumatoid factor ( $\mathrm{RF}$ ) was present (Table 1). A digital skin biopsy showed changes characteristic of PSS. A lip biopsy showed mild infiltration of mononuclear cells and fibrosis (Fig. 1).. The diagnosis of SS with PSS was made on the basis of these results, and the patient remained under our observation thereafter. LE test results and anti-nuclear antibody (ANA) became positive during the 7-year period, and hypergammaglobulinemia remained. In 1983 , the patient was admitted because of bilateral parotid gland swelling and generalized lymphadenopathy. A mediastinal mass, $10 \times 10 \mathrm{~cm}$ in diameter, was present on the chest roentgenogram.

Table 1. Clinical and Laboratory Data in Patients with Malignant Lymphomas associated with Autoimmune Diseases

\begin{tabular}{|c|c|c|c|c|c|c|}
\hline $\begin{array}{l}\text { Case No. } \\
\text { Age/Sex }\end{array}$ & $\begin{array}{c}1 \\
67 / F\end{array}$ & $\begin{array}{c}2 \\
34 / F\end{array}$ & $\begin{array}{c}3 \\
77 / F\end{array}$ & $\begin{array}{c}4 \\
70 / F\end{array}$ & $\begin{array}{c}5 \\
56 / F\end{array}$ & $\begin{array}{c}6 \\
70 / F\end{array}$ \\
\hline ML/Stage & $\mathrm{NHL}(\mathrm{B}) / 3 \mathrm{~B}$ & NHL (B) /4B & NHL (B) /1E & $\mathrm{NHL}(\mathrm{B}) / 4 \mathrm{~B}$ & NHL (B) $/ 4 \mathrm{~B}$ & $\mathrm{NHL}(\mathrm{T}) / 2 \mathrm{~A}$ \\
\hline $\mathrm{SmIg} / \mathrm{CIg}$ & $\operatorname{Ig} \mathrm{MK} /-$ & $\operatorname{Ig} M L / \operatorname{Ig} M L$ & nd/IgML & $\mathrm{nd} / \mathrm{IgGL}$ & IgML/IgML & - \\
\hline Histology & DM & DM & $\mathrm{DL}$ & DL & FMx & DL \\
\hline Autoimmune Dis. & SS/PSS & SLE & $\mathrm{RA} / \mathrm{SS}$ & SS & SS & ChTD/ITP \\
\hline Duration (Yrs) & $11 / 11$ & 5 & $30 / 1$ & 4 & 2 & $0 / 0$ \\
\hline Steroid/Immunsup. & - & mPSL & - & - & - & - \\
\hline Autopsy & yes & yes & alive & yes & alive & alive \\
\hline $\operatorname{ESR}(\mathrm{mm} / \mathrm{hr})$ & $* 32 / 91 * *$ & ${ }^{*} 41 / 43^{* *}$ & ${ }^{*} 43 / 21^{* *}$ & 52 & 24 & 25 \\
\hline $\mathrm{LDH}(\mathrm{U} / \mathrm{L})$ & $196 / 340$ & $181 / 885$ & $211 / 279$ & 1074 & 475 & 208 \\
\hline $\mathrm{TP}(\mathrm{g} / \mathrm{dl})$ & $8.1 / 6.3$ & $5.7 / 5.3$ & $6.4 / 6.5$ & 5.4 & 5.4 & 7.6 \\
\hline gamma-gl(g/dl) & $2.0 / 0.9$ & $1.9 / 1.1$ & $0.9 / 1.0$ & 1.6 & 0.9 & 0.9 \\
\hline $\operatorname{IgG}(\mathrm{mg} / \mathrm{d} \mathrm{l})$ & $2488 / 1145$ & $2000 / 1380$ & $980 / 1110$ & 1720 & 1091 & 1519 \\
\hline $\operatorname{Ig} \mathrm{A}(\mathrm{mg} / \mathrm{dl})$ & $390 / 236$ & $206 / 302$ & $144 / 159$ & 30 & 436 & 382 \\
\hline $\operatorname{IgM}(\mathrm{mg} / \mathrm{dl})$ & $162 / 138$ & $264 / 145$ & $451 / 430$ & 311 & 33 & 48 \\
\hline $\mathrm{C} 3(\mathrm{mg} / \mathrm{dl})$ & $61 / 80$ & $10 / 22$ & nd $/ 62$ & 84 & 66 & 74 \\
\hline $\mathrm{C} 4(\mathrm{mg} / \mathrm{dl})$ & $34 / 32$ & $5 / 7$ & $\mathrm{nd} / 16$ & 25 & 18 & 22 \\
\hline ANA & $+1-$ & $+1-$ & $\mathrm{nd} /+$ & - & - & - \\
\hline LE Test & $+1-$ & $+1-$ & nd / - & - & - & - \\
\hline RF & $+1-$ & $-1-$ & $+1+$ & - & - & - \\
\hline BFP & $-1-$ & $+1-$ & $-1-$ & - & - & - \\
\hline Thyrold test & $-1-$ & nd $/-$ & nd $/-$ & - & - & - \\
\hline Microsome test & $-1-$ & nd / - & nd $/-$ & - & - & + \\
\hline $\mathrm{RBC}\left(\times 10^{12} / \mathrm{L}\right)$ & $3.98 / 3.65$ & $5.24 / 3.36$ & $3.35 / 4.00$ & 4.19 & 2.49 & 4.29 \\
\hline $\mathrm{WBC}\left(\times 10^{9} / \mathrm{L}\right)$ & $3.8 / 5.7$ & $8.1 / 6.6$ & $7.3 / 4.8$ & 8.1 & 38.9 & 4.0 \\
\hline Lymph $\left(\times 10^{9} / \mathrm{L}\right)$ & $1.4 / 1.1$ & $1.2 / 1.5$ & $1.2 / 0.86$ & 0.57 & 33.4 & 0.74 \\
\hline $\mathrm{E}-\mathrm{RFC}(\%)$ & $53 / 55$ & $43 / 61$ & $\mathrm{nd} / 53$ & nd & 48 & 84 \\
\hline EAC-RFC $(\%)$ & $10 / 1$ & $20 / 8$ & nd $/ 3$ & nd & 2 & 6 \\
\hline Platelet $\left(\times 10^{9} / \mathrm{L}\right)$ & $180 / 246$ & $313 / 183$ & $228 / 294$ & 731 & 81 & 267 \\
\hline Blst. Resp. & N.N.N/D.N.N & $\mathrm{D} / \mathrm{D}$ & nd & nd & D.D.D & N.N.N \\
\hline DTH & N.N.D/D.N.N & $\mathrm{D} / \mathrm{D}$ & $\mathrm{nd} / \mathrm{D}$ & nd & D.D.D & $\mathrm{D}$ \\
\hline
\end{tabular}

NHL; non-Hodgkin's lymphoma, DM and DL; diffuse medium-sized and large cell type, FMx; follicular mixed cell type, mPSL; methylprednisolone, * 2 to 5 years before the diagnosis of malignant lymphoma, ** at the time of the diagnosis of malignant lymphoma, Blast. Resp.; blastogenic response to PHA, ConA and PWM, DTH; skin delayed-type hypersensitivity reactions to one to 3 antigens, nd; not done, $\mathrm{D}$ and $\mathrm{N}$; decreased and normal response. 

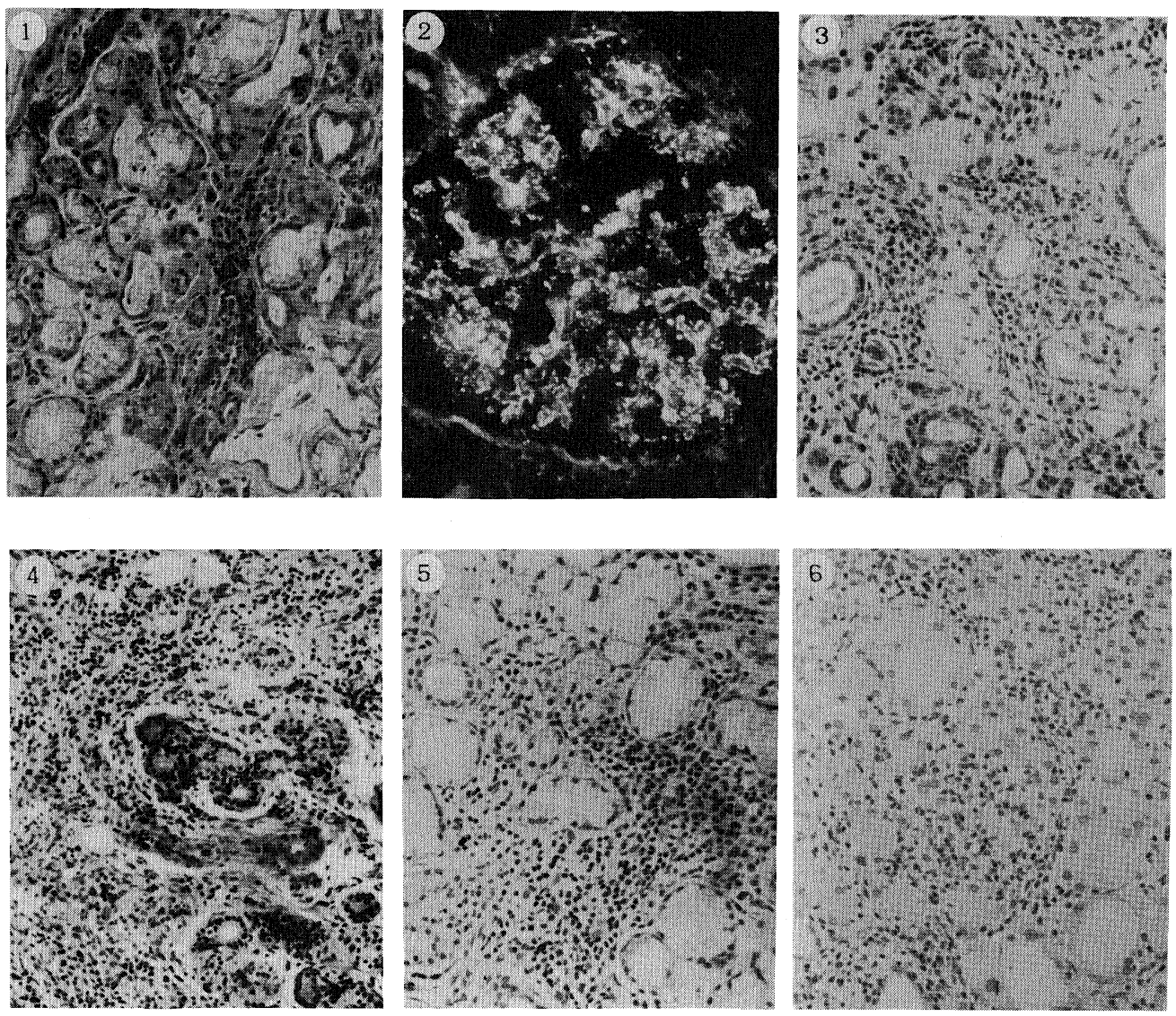

Fig. 1. Histologic pictures of salivary glands showing mononuclear cell infiltration in patients 1,3 , 4 and $5(1,3-5)$ and a thyroid gland infiltrated by lymphocytes in patient $6(6)$, and a glomerulus stained with anti-Clq antibody by the immunofluorescence method in patient 2 (2).

Laboratory examination showed ESR $91 \mathrm{~mm} / \mathrm{hr}$ and lactic dehydrogenase (LDH) $340 \mathrm{U} / \mathrm{L}$ (Table 1). A lymph node biopsy revealed malignant lymphoma of the diffuse, medium-sized cell type (Fig. 2), according to the Lymphoma Study Group (LSG) classification ${ }^{17)}$. The $\mathrm{B}$ cell nature of lymphoma was identified by positive SmIgM-K (78.6$69.5 \%$ ) and negative CIg. The diagnosis of stage $3 \mathrm{~A}$ was made by ${ }^{67} \mathrm{Ga}$ whole body scintigraphy, liver and spleen scintigraphy and bone marrow biopsy. The patient was treated with COPP regimen (cyclophosphamide, vincristine, procarbazine and prednisolone), and she entered complete remission. After 3 courses of this therapy the patient developed acute interstitial pneumonitis and died of respiratory failure in May, 1983.

Postmortem examination revealed a lymphoma, $5.0 \times 4.0 \mathrm{~cm}$ in diameter, in the carinal region which was necrotic, but no malignant cells were found in any other organ. Pulmonary fibrosis and abnormal fibrosis of the esophagus and heart muscles with non-bacterial thrombotic endocarditis were disclosed.

Case 2. The patient was a 34-year-old woman with B cell lymphoma and SLE whose clinical details have been described previously ${ }^{18)}$. The onset of facial skin rash and urticaria occurred in 1975 . Raynaud's phenomenon, edema, pleural effusion and ascites developed in 1978, and the diagnosis of SLE was made on the basis of these signs, biological false-positive reaciton, low C3 titer and renal biopsy findings. "Pulse" therapy with $1,000 \mathrm{mg}$ methylprednisolone/day for 3 days was administered, after which symptoms and signs disappeared. In December 1979, she developed paralysis of both legs and urinary incontinence. Emergency laminectomy revealed compression of the spinal cord by malignant lymphoma (diffuse, medium-sized cell 

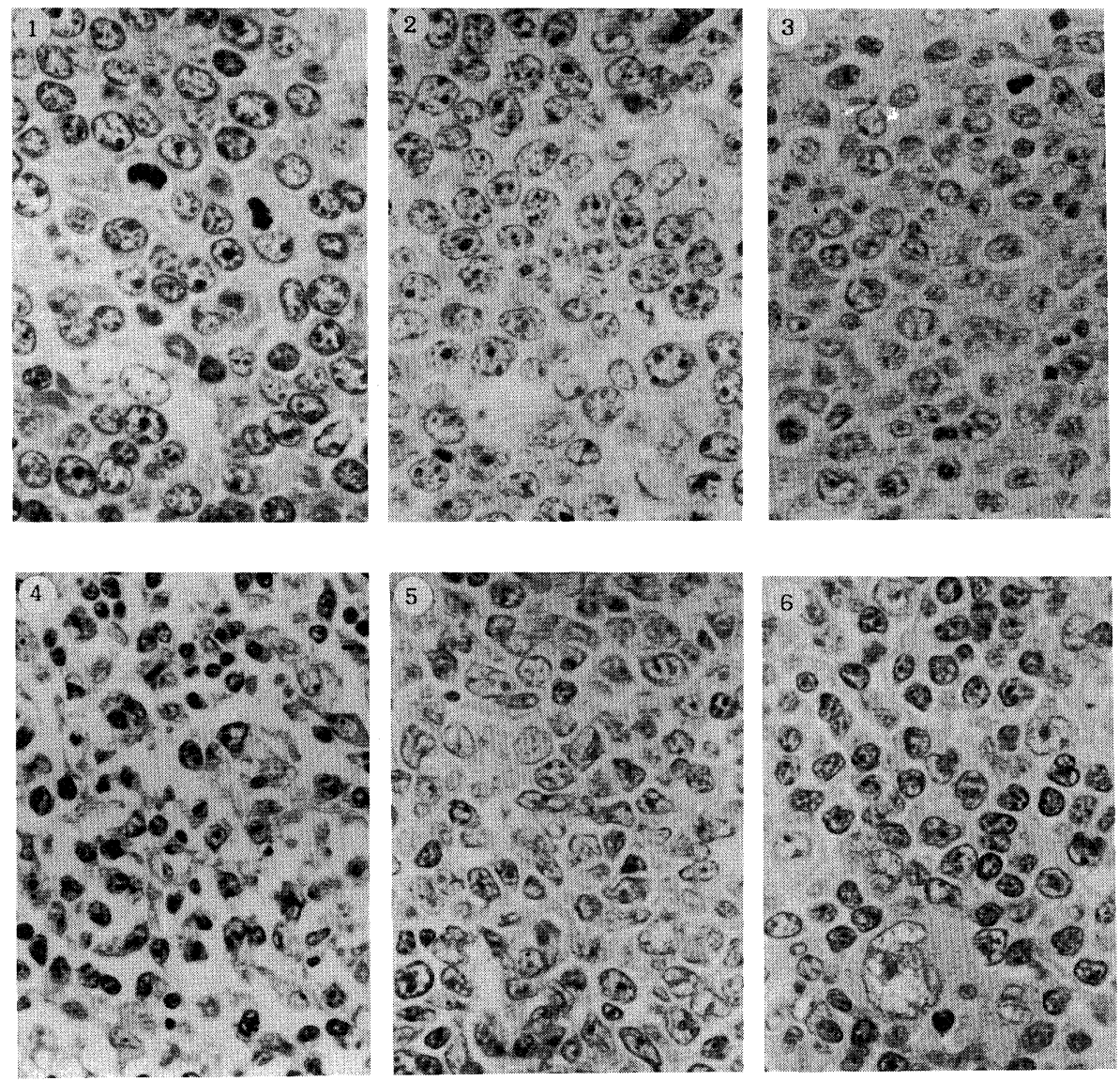

Fig. 2. Histologic pictures of lymphoma cells in patients $1,4,5$ and 6 (lymph nodes), patient 2 (bone marrow) and in patient 3 (a subcutaneous tumor).

type). Laboratory studies revealed that serum total protein was $5.3 \mathrm{~g} / \mathrm{dl}$ and the titer of $\mathrm{C} 3$ and $\mathrm{C} 4$ was 22 and $7 \mathrm{mg} / \mathrm{dl}$, respectively (Table 1 ). Bone marrow aspiration and biopsy (Fig. 2) at the iliac bone showed involvement of abnormal lymphoid cells $(67.5 \%)$. These cells contained SmIgM-L (50.4-49.5\%) and CIgM-L (46.3-45.3\%). The patient was treated with spinal irradiation of 3,000 rads, followed by COP regimen. In March 1980, large pathologic cells appeared in the peripheral blood $(66.0 \%)$. She developed meningeal involvement and pneumonia, and died of respiratory failure.

Although the serum electrophoresis on a cellulose acetate membrane or immunoelectrophoresis did not show any monoclonal protein, purified serum IgM showed monoclonal characteristics of IgM-L through the double diffusion method. Antiidiotypic antiserum was prepared against the IgM-
L, as previously described ${ }^{18)}$. A cell line was established from the bone marrow cells. The cell surface and cytoplasm of the cultured cells were stained by anti-idiotypic antiserum, indicating that lymphoma cells produced and secreted a small amount of IgM-L in the serum.

A postmortem study revealed the presence of malignant lymphoma of the diffuse, medium-sized cell type, involving the cervical lymph nodes, liver, spleen, stomach, uterus, ovaries, bone marrow, lungs and salivary glands. SLE was confirmed by onion skin lesions of the splenic arteries and membranous glomerulohephritis with deposition of IgG, IgM, C3 and Clq (Fig. 1) along the basement membranes. A uterine leiomyoma was disclosed, and there was a gastric ulcer due to malignant cell invasion.

Case 3. The patient is a 77-year-old woman with B cell lymphoma and SS with RA. The pa- 
tient noticed the onset of polyarthralgia about 30 years ago. Raynaud's phenomenon and xerostomia developed about 20 years ago, and since then both of her wrists have become deformed. In 1980, the patient exhibited the symptoms of dry eyes and increasing polyarthralgia. She was then admitted to a hospital and was examined by one of our physicians. Physical examination revealed ankylosing deformity of the wrists, fingers and toes. Angular cheilitis was present. Pulmonary fibrosis and cardiomegaly were disclosed on a chest roentgenogram. Elevated ESR, mild anemia, and hypergammaglobulinemia with a high titer of RF were evident (Table 1). The diagnosis of classical RA was made and gold salt therapy was begun. In November 1983, she noticed nontender swelling on the left pretibial region. On examination, a non-movable, elastic firm subcutaneous mass, $5.0 \times 4.0 \mathrm{~cm}$ in diameter, was discovered on the left upper pretibial region. Laboratory studies showed RF in titer of $1 ; 20,480$, ANA in titer of $1 ; 320, \mathrm{IgG}$ $1,110, \operatorname{IgA} 159, \operatorname{IgM} 430 \mathrm{mg} / \mathrm{dl}$ and C4 $16.5 \mathrm{mg} / \mathrm{dl}$ (Table 1). Schirmer's test result was $1 \mathrm{~mm} / 5 \mathrm{~min}$ bilaterally with positive rose bengal staining tests. Salivary scintigraphy revealed abnormality and a lip biopsy showed mononuclear cell infiltration and destruction of acini (Fig. 1). Surgical resection of the mass revealed malignant lymphoma of the diffuse, large cell type (Fig. 2) which had infiltrated the surrounding subcutaneous tissues and muscles. Intracytoplasmic IgM-L was identified in lymphoma cells by the immunoperoxidase method. Treatment consisted of local irradiation with 3,000 rads under the diagnosis of stage $1 \mathrm{E}$. The patient is doing well (June, 1987).

Case 4 . The patient was a 70 -year-old woman with B cell lymphoma and SS. The patient was healthy until 1971 when she suffered from acute pneumonia and was admitted to a hospital for 2 months. After her discharge, she started noticing dry mouth and painful bilateral parotid swelling. Anemia was diagnosed in 1972, and she received a $1,200 \mathrm{ml}$ blood transfusion. After that time, she complained of dry mouth, general malaise and loss of appetite. In November 1975, she noticed tarry stool associated with left back pain and weight loss, and was admitted to our hospital. Physical examination revealed emaciation, hepatomegaly, a small mass in the left hypochondrial region and pretibial edema. Laboratoty studies showed proteinuria and fecal occult blood. ESR was $52 \mathrm{~mm} /$ $\mathrm{hr}$, total protein was $5.4 \mathrm{~g} / \mathrm{dl}$ and $\mathrm{LDH}$ was 1,074 U/L (Table 1). Salivary flow had decreased and rose bengal staining was positive. Barium enema examination revealed diffuse irregular narrowing and sclerotic change of the transverse and descending colon which were compatible with advanced carcinoma. The patient died of massive rectal bleeding in December, 1975.

A postmortem study revealed malignant lymphoma of the diffuse, large cell type, involving the transverse and descending colon, stomach, pancreas, spleen, left kidney, right adrenal gland, mediastinum, heart, left lung and multiple lymph nodes (Fig. 2) in the abdomen and in the mediastinum. Submandibular glands showed marked mononuclear cell infiltration with destruction of acini but no involvement of malignant cells (Fig. 1). There were epidermoid carcinoma in situ in the uterine cervix and tuberculous granuloma in the liver. Immunoperoxidase staining showed monoclonal cytoplasmic IgG-L in lymph node cells.

Case 5. The patient is a 56-year-old woman with B cell lymphoma and SS. She first noticed parotid pain and swelling 10 years ago. For 5 years she had had Raynaud's phenomenon in her left fingers and arthralgia in her knee joints and wrists. She had had symptoms of dry mouth and xerostomia for 2 years. She noticed a mass in the right side of her neck and right axillary region in the spring of 1984. In January, 1985, she developed another mass in the right inguinal region with swelling of the right thigh and abdominal distention, and was admitted to our hospital. Physical examination revealed anemia, generalized lymphadenopathy, hepatosplenomegaly with ascites and edema of the right leg. Laboratory studies showed that ESR was $24 \mathrm{~mm} / \mathrm{hr}$, total serum protein 5.4 g/dl, LDH $475 \mathrm{U} / \mathrm{L}, \mathrm{RBC} 2.49 \times 10^{12} / \mathrm{L}, \mathrm{WBC}$ $38.9 \times 10^{9} / \mathrm{L}$ with $85 \%$ abnormal lymphoid cells, and platelets were $81 \times 10^{9} / \mathrm{L}$ (Table 1). Bilateral pleural effusion was disclosed on a chest roentgenogram. ${ }^{67} \mathrm{Ga}$ scintigraphy and computerized tomography revealed bilateral masses, about $20 \times$ 10 and $10 \times 5 \mathrm{~cm}$ in diameter, in the lower abdomen. Bone marrow was massively involved with abnormal lymphoid cells (94\%). A lymph node biopsy showed malignant lymphoma of the follicu- 
lar, mixed-cell type (Fig. 2); monoclonal SmIgML (16.5-15.6\%) and CIgM-L (23.5-23.7\%) were identified on and in the lymphoma cells. Salivary flow rates had decreased and KCS was present. Sequential salivary scintigraphy was abnormal and a lip biopsy revealed mononuclear cell infiltration and acinar cell destruction (Fig. 1) but no malignant cells were discovered. The patient was treated with a COP regimen and is presently doing well (June 1986).

Case 6. The patient is a 70-year-old woman with $\mathrm{T}$ cell lymphoma accompanied by ChTD and ITP. The patient was healthy until March 1983 when she noticed a lymph node swelling in the right side of her neck. In April 1984, she noticed diffuse swelling of the anterior portion of the neck. She was admitted to a hospital and a lymph node biopsy led to the diagnosis of Hodgkin's lymphoma of the lymphocyte predominant type. For further examination, she was transferred to our hospital. Bilateral cervical lymph node swelling

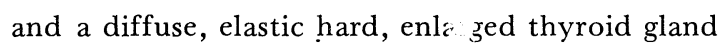
were palpable. Laboratory studies showed that $\mathrm{T} 3$ was $1.21 \mathrm{ng} / \mathrm{ml}$, thryroid stimulatory hormone (TSH) $66.7 \mu \mathrm{g} / \mathrm{ml}$, anti-microsomal antibody in titer of $1 ; 51,200$, and fasting blood sugar (FBS) $280 \mathrm{mg} / \mathrm{dl}$ with abnormal glucose tolerance test results. Other results are included in Table 1. A thyroid gland biopsy exhibited diffuse mononuclear cell infiltration and destruction of follicles which are compatible with ChTD (Fig. 1). The diagnosis of non-Hodgkin's lymphoma of the diffuse, large cell type was established by another lymph node biopsy performed in our hospital (Fig. 2 ). The $\mathrm{T}$ cell characteristics of the lymphoma (OKT3-95.0\%, T4-80.0) were confirmed. Irradiation of the bilateral cervical lymph node areas was started under stage 2A diagnosis. After irradiation of 1,200 rads, she developed pancytopenia of RBC $2.79 \times 10^{12} / \mathrm{L}$, WBC $3.1 \times 10^{9} / \mathrm{L}$ and platelets 12 $\times 10^{9} / \mathrm{L}$. Abundant megakaryocytes were seen on bone marrow smears and biopsied specimens. Platelet counts rapidly returned to normal levels with high doses of intravenous gammaglobulin therapy and the diagnosis of ITP was made according to these results. The patient is currently in remission (June, 1987) through treatment with cyclophosphamide, vincristine, or intermittent transfusion of platelets coated with vincristine.

\section{DISCUSSION}

In the present study, we described 6 patients with malignant lymphomas associated with autoimmune diseases such as primary or secondary SS, SLE and ChTD/ITP. Among these malignant lymphomas, 5 B cell lymphomas were preceded by autoimmune diseases (SS or SLE). It is notable that the decline of the IgG level and disappearance of autoantibodies in patients 1 and/or 2 occurred at the time of malignant lymphoma development. The results of such autoantibodies were also negative in SS patients 4 and 5, whereas ANA and RF were still positive in patient 3 , in whom malignant lymphoma was in the $1 \mathrm{E}$ stage. It was pointed out by Talal et $\mathrm{al}^{1)}$ that an early decline in gammaglobulin might be the first manifestation of a neoplasm which was not yet clinically detectable.

We reviewed the Japanese literature and academic records of lymphoproliferative disorders associated with SS. Seventy-five such disorders were found (Table 2); there were 25 patients with non-Hodgkin's lymphoma, 8 with pseudolymphoma, 2 with plasmacytoma, 2 with thymoma, one with chronic lymphocytic leukemia and 37 with monoclonal gammopathy. Among 25 nonHodgkin's lymphomas, 10 patients were of the B cell type which was documented by SmIg and/or CIg. We also reviewed the literature on lymphoproliferative disorders in non-Japanese SS patients and found 137 such patients. There were 64 patients with non-Hodgkin's lymphoma (11 B cell type and one T cell type), 4 with Hodgkin's lymphoma, 4 with immunoblastic lymphadenopathy, 23 with pseudolymphoma, 27 with monoclonal gammopathy and others (Table 2). These data indicate that non-Hodgkin's lymphomas, monoclonal gammopathies and pseudolymphomas frequently occurred among lymphoproliferative disorders associated with SS and that B cell lymphomas were more common in non-Hodgkin's lymphomas. In regards to monoclonal gammopathy, we previously stated that there was a higher incidence of monoclonal gammopathy in primary than in secondary SS and that non-IgM class monoclonal gammopathy predominated in Japanese SS patients ${ }^{15,19)}$. It appears that monoclonal gammopathy occurs more frequently in Japanese than in non-Japanese SS patients, but it does not 
Table 2. Lymphoproliferative Disorders in Patients with Sjögren's Syndrome

\begin{tabular}{|c|c|c|c|c|c|c|}
\hline \multirow{2}{*}{ Report No. } & \multicolumn{3}{|c|}{$\begin{array}{c}\text { Japanese } \\
(70)\end{array}$} & \multicolumn{3}{|c|}{$\begin{array}{c}\text { Non-Japanese } \\
(89)\end{array}$} \\
\hline & Cases & M & $\mathrm{F}$ & Cases & $\mathrm{M}(\mathrm{W} / \mathrm{B})$ & $F(W / B)$ \\
\hline Non-Hodgkin's lymphoma & 25 & 2 & 22 & 64 & $12(1 / 0)$ & $49(9 / 1)$ \\
\hline Hodgkin's disease & 0 & & & 4 & 2 & 2 \\
\hline IBL & 0 & & & 4 & 2 & 2 \\
\hline Pseudolymphoma & 8 & 2 & 6 & 23 & 1 & $21(10 / 0)$ \\
\hline Plasmacytoma & 2 & 1 & 1 & 0 & & \\
\hline CLL & 1 & & & 1 & 0 & 1 \\
\hline Thymoma & 2 & 0 & 2 & 5 & 0 & 2 \\
\hline Lennert's lymphoma & 0 & & & 2 & 0 & 2 \\
\hline \multirow[t]{2}{*}{ Undetermined LPD } & 0 & & & 7 & 2 & $5(2 / 0)$ \\
\hline & 38 & 5 & 31 & 110 & $19(1 / 0)$ & $84(21 / 1)$ \\
\hline \multicolumn{7}{|l|}{ Monoclonal gammopathy } \\
\hline $\operatorname{Ig} \mathrm{M}$ & 11 & 4 & 7 & 20 & $5(3 / 0)$ & $13(2 / 0)$ \\
\hline $\operatorname{IgG}$ & 6 & 0 & 6 & 4 & 0 & $4(2 / 0)$ \\
\hline $\operatorname{Ig} \mathrm{A}$ & 17 & 1 & 15 & 2 & 0 & $2(1 / 0)$ \\
\hline $\operatorname{Ig} M / \operatorname{IgG}$ & 1 & 0 & 1 & 0 & & \\
\hline $\operatorname{IgG} / \operatorname{Ig} A$ & 1 & 0 & 1 & 0 & & \\
\hline \multirow[t]{2}{*}{$\mathrm{BJ}$ protein } & 1 & 0 & 1 & 1 & 0 & $1(1 / 0)$ \\
\hline & 37 & 5 & 31 & 27 & $5(3 / 0)$ & $20(6 / 0)$ \\
\hline Total & 75 & 10 & 62 & 137 & $24(4 / 0)$ & $104(27 / 1)$ \\
\hline
\end{tabular}

IBL, immunoblastic lymphadenopathy; CLL, chronic lymphocytic leukemia; LPD, lymphoproliferative disorder; M, male; F, female; W, white; B, black.

seem to be reasonable to discuss the frequency of monoclonal gammopathy between two groups because we searched as many reports as possible including abstracts of academic meetings in Japanese patients but in the cases of non-Japanese SS patients we could find only cases of full papers.

Talal and Bunim ${ }^{1)}$ described 3 cases of malignant lymphoma and one case of Waldenström's macroglobulinemia among 58 SS patients in 1964 . Since their report, many others have supported the association of SS with various lymphoproliferative disorders. Kassan et $\mathrm{al}^{2}$ ) reported that patients with SS have an increased risk of non-Hodgkin's lymphoma that is 43.8 times higher than the control group, and a probable high risk of Waldenström's macroglobulinemia. They pointed out that the risk of lymphoma is related to extensive lymphoproliferation such as parotid swelling, splenomegaly and lymphadenopathy. According to Moutsopoulos and $\mathrm{Fauci}^{20)}$, a spectrum of immunoregulatory disorders in SS ranges from restricted hyperactivity of the B cell function and reversible abnormalities of immunoregulatory $\mathrm{T}$ cells to the more broadly expressed B cell hyperactivity and irreversible abnormalities of immunoregulatory $\mathrm{T}$ cells which are usually seen in SLE. This process is similar to that which occurs in NZB/NZW F1 mice. Talal ${ }^{21)}$ reported that there is a marked similarity in autoimmunity and lymphoid malignancy between SS and New Zealand mice which have been considered to be suitable models for human autoimmune diseases such as $\mathrm{SLE}^{22)}$ and $\mathrm{SS}^{23)}$. At a young age these mice develop autoimmune diseases and later on, lymphoid malignancy or macroglobulinemia ${ }^{22,24)}$. The hyperactive state of $\mathrm{B}$ cell function and disordered $\mathrm{T}$ cell function may represent a link between SS and the development of malignant lymphoma.

A review of the Japanese literature on lymphoproliferative disorders associated with other autoimmune diseases such as SLE, RA, PSS, ChTD and ITP disclosed 15 such patients in SLE, 19 patients in RA, 5 patients in PSS, 8 patients in ITP and 6 lymphoproliferative disorders outside of the thyroid gland in patients with ChTD (Table 3). SLE, RA, ChTD and ITP are all known to be 
Table 3. Lymphoproliferative Disorders in Japanese Patients with Autoimmune Diseases

SLE RA PSS ITP ChTD*

\begin{tabular}{lrrrrr} 
Report No. & $(14)$ & $(18)$ & (5) & (5) & (6) \\
\hline Non-Hodgkin's lymphoma & 12 & 11 & 2 & 2 & 4 \\
Hodgkin's disease & 0 & 2 & 1 & 1 & 0 \\
Plasmacytoma & 0 & 1 & 0 & 0 & 0 \\
ALL & 0 & 0 & 0 & 1 & 0 \\
Undetermined LPD & 0 & 0 & 0 & 1 & 0 \\
Monoclonal gammopathy & & & & & \\
WM & 1 & 0 & 0 & 0 & 0 \\
MM & 1 & 2 & 0 & 1 & 0 \\
BMG & 1 & 3 & 2 & 2 & 2 \\
\hline Total & 15 & 19 & 5 & 8 & 6 \\
\hline
\end{tabular}

ALL acute lymphocytic leukimia;

WM, macroglobulinemia; MM, multiple myeloma;

BMG, benign monoclonal gammopathy

*Lymphoproliferative disorders outside of the thyroid gland.

found associated with lymphoid malignancy and the association is considered to be significant $^{4,6,8,10)}$. Systematic survey on malignant lymphomas in autoimmune diseases has not been done in Japan except for the report on SLE by Ichikawa et $\mathrm{al}^{25)} ; 2$ cases of malignant lymphoma out of 212 death $(0.94 \%)$ was recorded in SLE patients between 1973 and 1983. The incidence of malignant lymphoma in the general Japanese population is 4.77 (male 3.18 and female 1.59 ) out of 100,000 by Aoki et $\mathrm{al}^{26)}$. On the basis of these reports, malignant lymphoma occurs at a higher rate in Japanese SLE patients than in the general population (196 times), but more studies are needed to clarify the high incidence of malignant lymphoma in SLE and other autoimmune diseases in Japan. A high dose of methylprednisolone was administered to patient 3 . Whether this treatment increased the risk of lymphoma is unknown at present, but Louie and Schwartz ${ }^{27)}$, who reviewed malignant tumors in patients receiving immunosuppressive therapy for nonmalignant diseases, suggested that SLE patients have an increased risk of cancer, especially lymphoma, regardless of the therapy used. The overall immune status in SLE has been suggested to be an imbalance in which $\mathrm{T}$ cell activity is depressed and B cell activity is enhanced ${ }^{22,28)}$. There are fewer suppressor $\mathrm{T}$ cells in patients with $\mathrm{SLE}^{29)}$, which play an important role in control- ling autoantibody formation and this $\mathrm{T}$ cell defect could result in a predisposition for the emergence of malignant lymphoma.

In our review of the literature on lymphoproliferative disorders in non-Japanese patients with SLE, RA and PSS, we found 62 such patients with SLE (25 non-Hodgkin's lymphomas, 15 Hodgkin's lymphomas, 2 immunoblastic lymphadenopathies, 2 thymomas, one multiple myeloma and 9 other monoclonal gammopathies and others), 261 patients with RA (119 non-Hodgkin's lymphomas, 37 Hodgkin's lymphomas, 45 multiple myelomas and others) and 18 patients with PSS (3 nonHodgkin's lymphomas, 4 Hodgkin's lymphomas, 5 multiple myelomas and 3 other monoclonal gammopathies and others). The high rates of pseudolymphoma, monoclonal gammopathy and malignant lymphoma (especially B cell type) in patients with SS, the low rates of monoclonal gammopathy and the relatively high rates of Hodgkin's lymphoma in SLE and the high rates of multiple myeloma in RA varied considerably. Regarding PSS, it is notable that very few PSS patients with associated malignant lymphomas have been reported, although alveolar cell carcinomas are known to be highly associated with PSS. Although ITP was reported more often in patients with B cell malignancy such as chronic lymphocytic leukemia, than would be expected from a chance association ${ }^{30,31)}$, we found only 3 malignant lymphomas in Japanese ITP patients. Holm et $\mathrm{al}^{8}$ ) recently reported that patients with ChTD had an increased risk of malignant thyroid lymphomas. These data might indicate that differences among immunological disorders in these autoimmune diseases have some relation to the differences in the developmental rate and the kind of lymphoproliferative disorders found in autoimmune diseases. It is not clear at present that there is a difference of types of lymphoproliferative disorders between Japanese and non-Japanese autoimmune diseases because of a small number in each type of lymphoproliferative disorders in Japanese patients. There is evidence in both animals and humans that increased suppressor cell activity is associated with the development or enhancement of certain types of cancer ${ }^{32}$ ). The proper function of the immune system depends upon the appropriate regulation of suppression as 
well as of effector $\mathrm{T}$ and $\mathrm{B}$ lymphocytes. The autoimmune disorders may cause disturbances to this regulatory function resulting in the inability to suppress emerging malignant cell growth.

\section{REFERENCES}

1) Talal N, Bunim JJ: The development of malignant lymphoma in the course of Sjögren's syndrome. Am J Med 36: 529, 1964.

2) Kassan SS, Thomas TL, Moutsopoulos HM, et al: Increased risk of lymphoma in sicca syndrome. Ann Inter Med 89: 888, 1978.

3) Goldenberg GJ, Paraskevas F, Israels LG: The association of rheumatoid arthritis with plasma cell and lymphocytic neoplasms. Arthritis Rheum 12: 569, 1969.

4) Isomäki HA, Hakulinen T, Joutsenlahti U: Excess risk of lymphomas, leukemia and myeloma in patients with rheumatoid arthritis. Ann Rheum Dis 41 (Suppl): 34, 1982.

5) Lewis RB, Castor CW, Kinsley RE, et al: Frequency of neoplasia in systemic lupus erythematosus and rheumatoid arthritis. Arthritis Rheum 19: 1256, 1976.

6) Green JA, Dawson AA, Walker W: Systemic lupus erythematosus and lymphoma. Lancet 2: 753, 1978.

7) Compagno J, Oertel JE: Malignant lymphoma and other lymphoproliferative disorders of the thyroid gland. Am J Clin Pathol 74: 1, 1980.

8) Holm L-E, Blomgren $H$, Löwhagen $T$ : Cancer risks in patients with chronic lymphocytic thyroiditis. $\mathrm{N}$ Engl J Med 312: 601, 1985.

9) Kirshner JJ, Zamkoff KW, Gottlieb AJ: Case report. Idiopathic thrombocy topenic purpura and Hodgkin's disease: report of two cases and a review of the literature. Am J Med Sci 280: 21, 1980.

10) Jones SE: Autoimmune disorders and malignant lymphoma. Cancer 31: 1092, 1973.

11) Anderson LG, Talal N: The spectrum of benign to malignant lymphoproliferation in Sjögren's syndrome. Clin Exp Immunol 10: 199, 1972.

12) Zulman J, Jaffe R, Talal N: Evidence that the malignant lymphoma of Sjögren's syndrome is a monoclonal B-cell neoplasm. N Engl J Med 299: 1215, 1978.

13) Sugai S, Konaka Y, Konda S: Two cases of hypergammaglobulinemic purpura associated with Sjögren's syndrome. Acta Haematol Jpn 41: 127, 1978.

14) Jondal M, Holm G, Wigzell H: Surface markers on human $\mathrm{T}$ and $\mathrm{B}$ lymphocytes. I. A large population of lymphocytes forming nonimmune rosettes with sheep red blood cells. J Exp Med 136: 207, 1972.

15) Sugai S, Shimizu S, Hirose $Y$, et al: Monoclonal gammopathies in Japanese patients with Sjögren's syndrome. J Clin Immunol 5: 90, 1985.

16) Pincus GS, Said JW: Specific identification of intracellular immunoglobulin in paraffin sections of multiple myeloma and macroglobulinemia using an immunoperoxidase technique. Am J Pathol 87: 47, 1977.

17) Suchi $T:$ A new pathological classification of nonHodgkin's lymphoma. Atlas of Malignant Lymphoma by the New Classification (Kojima M, Iijima S, Hanaoka M, Suchi T, eds), Bunkodo, Tokyo, p 27, 1981 (in Japanese).

18) Sugai $S$, Takiguchi T, Konda S, et al: Systemic lupus ery thematosus developing malignant lymphoma with monoclonal IgM: Case report. Acta Haematol Jpn 47: 113, 1984.

19) Sugai $S$, Konda S, Shirasaki $Y$, et al: Non-IgM monoclonal gammopathy in patients with Sjögren's syndrome. Am J Med 68: 861, 1980.

20) Moutsopoulos HM, Fauci AS: Immunoregulation in Sjögren's syndrome. Influence of serum factors on T-cell subpopulations. J Clin Invest 65: 519, 1980.

21) Talal N: Autoimmunity and lymphoid malignancy in New Zealand black mice. Prog Clin Immunol 2: 101, 1974.

22) Talal N, Steinberg AD: The pathogenesis of autoimmunity in New Zealand black mice. Curr Topics Microbiol Immunol 64: 79, 1974.

23) Kessler HS: A laboratory model for Sjögren's syndrome. Am J Path 52: 671, 1968.

24) Sugai S. Pillarisetty RJ, Talal N: Monoclonal macroglobulinemia in NZB/NZW F1 mice. J Exp Med 138: $989,1973$.

25) Ichikawa Y, Tsunematsu T, Sugai S, et al: Cooperative studies on death in systemic lupus erythematosus. The 2nd report: Its change by duration of disease and periods. Annual Report of the Ministry of Health and Welfare, Autoimmune Disease Research Committee, p 37, 1984 (in Japanese).

26) Aoki K, Ohno Y: Epideminology. No 39 All in Malignant Lymphoma, Naika Series (Sakano T, ed), Nankodo, Tokyo, p 21, 1978 (in Japanese).

27) Louie S, Schwartz RS: Immunodeficiency and the pathogenesis of lymphoma and leukemia. Semin Hematol 15: 117, 1978.

28) Deker JL, Steinberg AD, Reinertsen JL, et al: NIH conference. Systemic lupus erythematosus: Evolving concepts. Ann Intern Med 91: 587, 1979.

29) Abdou NI, Sagawa A, Pascual E, et al: Suppressor $T$-cell abnormality in idiopathic systemic lupus erythematosus. Clin Immunol Immunopathol 6: 192, 1976.

30) Carey RW, McGinnis A, Jacobson BM, et al: Idiopathic thrombocytopenic purpura complicating chronic lymphocytic leukemia. Arch Inter Med 136: 62,1976 .

31) Kim HD, Boggs DR: A syndrome resembling idiopathic thrombocytopenic purpura in 10 patients with diverse forms of cancer. Am J Med 67: 371, 1979.

32) Broder S, Waldmann TA: The suppressor-cell network in cancer. N Eng J Med 299: 1281, 1978. 